\title{
Body measurements and serum lipid profile of overweight adult dogs fed diet with containing conjugated linoleic acid
}

\author{
Medidas corporais e perfil lipídico plasmático de cães adultos com sobrepeso alimentados com dieta \\ contendo ácido linoléico conjugado
}

\author{
Nancy Lorena Montaño Rivera ${ }^{I}$ Ananda Portela Félix I Fabiano Montiani Ferreira ${ }^{I I}$ \\ Ana Vitória Fisher da Silva ${ }^{I I}$ Alex Maiorka ${ }^{{ }^{I *}}$
}

\begin{abstract}
Studies with human beings and animals have shown that dietary conjugated linoleic acid (CLA) promotes changes in body structure, markedly, body fat reduction. This research aimed to assess the effect of CLA (60\% of conjugated linoleic acid methyl ester, at the proportion of 1:1 of the 9, 11: 10, 12 isomers) on changes in body weight, subcutaneous tissue thickness, body fat mass and concentration of serum lipids (triacylglycerols, total cholesterol, LDL and HDL) in overweight dogs. Dogs of different breeds weighting 16.85 \pm 7.13 assigned in a randomized assay. Two types of diets were offered for 120 days: control (-CLA) and test $(+C L A, 0.3 \%)$. There was no difference between control and test groups considering body weight and serum levels of triacylglycerols, total cholesterol and LDL portion. There was a significant difference between the final and initial results for subcutaneous tissue thickness and body fat mass and for serum concentration of HDL in dogs supplemented with CLA. The addition of $0.3 \%$ of CLA in the diet of overweight dogs decreased the fat deposition on subcutaneous tissue and the development of body fat mass but increased blood levels of $H D L$.
\end{abstract}

Key words: body condition, cholesterol, CLA

\section{RESUMO}

Estudos em humanos e animais têm demonstrado que o uso do ácido linoléico conjugado $(A L C)$ promove alterações na composição corporal, principalmente reduzindo a deposição de gordura. O objetivo deste trabalho foi avaliar as alterações sobre o peso corporal, tecido adiposo subcutâneo, gordura corporal e concentração sérica de lípideos (triacilglicerol, colesterol total, $L D L$ e HDL) de cães com sobrepeso alimentados com ALC $(60 \%$ de ácido linoléico conjugado metil ester, na proporção de 1:1 de 9, 11: 10, 12

\begin{abstract}
isômeros) na dieta. Duas dietas foram fornecidas por quatro meses, para 14 cães com sobrepeso $(16,85 \pm 7,13)$ de diferentes raças: dietas controle $(-A L C)$ e teste $(+A L C, 0,3 \%)$. O experimento seguiu delineamento inteiramente casualizado. Não houve diferença entre os grupos para peso corporal $e$ nível sérico de triacilglicerol, colesterol total e LDL. No entanto, foram observadas diferenças significativas entre os períodos final e inicial para tecido adiposo subcutâneo, gordura corporal e nível sérico de $H D L$ nos cães que receberam $A L C$. A suplementação de 0,3\% de ALC na dieta de cães com sobrepeso diminuiu a deposição de lipídios no tecido subcutâneo e a gordura corporal total, mas aumentou os níveis sanguíneos de $H D L$.
\end{abstract}

Palavras-chave: ALC, colesterol, condição corporal.

\section{INTRODUCTION}

The prevalence of obesity in dogs has been increasing over the last few years. The same phenomenon is also occurring in human (GERMAN, 2006). The largest deposits of lipids are located under the skin as subcutaneous fat, around vital organs and at intestines. Some of these deposits can be easily seen in obese dogs and cats.

The body composition can be determined using different techniques with different degrees of precision, accuracy and costs. An estimation of total body fat can be evaluated through measurements of some parts of the body, as the waist circumference, region which reflects with greater consistency the total body fat (SHARON, 2003).

IPrograma de Pós-graduação em Medicina Veterinária, Universidade Federal do Paraná (UFPR), Curitiba, PR, Brasil.

"Departamento de Zootecnia, UFPR, Rua dos Funcionários, 1540, Bairro Cabral, 80035-050, Curitiba, PR, Brasil. E-mail: amaiork@ufpr.br. *Autor para correspondência. 
The conjugated linoleic acid (CLA) is a mixture of positional and geometrical isomers, and 9cis, 11-trans and 10-trans, 12-cis, are the most important ones (PARK \& PARIZA, 2007). The CLA proved to be an effective diet supplement to reduce fat in animals, increasing muscle mass (WHIGHAM et al., 2007). Moreover, animal model studies reported reduction on low density lipoprotein cholesterol and on triacylglycerol levels in blood (PARIZA, 2001). Thus, CLA might be an interesting diet supplement to prevent and/or treat obesity and cardiovascular diseases. However, studies reporting metabolic effects of CLA in animals still controversial. Variations in experimental conditions, including the CLA level in the diet and animal weight, might have contributed to those divergent results (CHOI et al., 2004). Therefore, changes in body composition and serum lipids concentration in overweight dogs were investigated in diets supplemented with CLA.

\section{MATERIAL AND METHODS}

\section{Animals and diets}

Fourteen overweight mixed breed dogs $(16.85 \pm 7.13)$ were randomly divided into two groups: control and test. All dogs selected presented body weight higher than $10-19 \%$ of their ideal weight to be considered overweight, according to BURKHOLDER $\&$ TOLL (2000).

The nutritional experiment was run for 120 days, and the first 30 days was used for the dogs' adaptation to the food, facilities and management. It was also conducted physical, hematological, biochemical and coproparasitological examinations to attest the dogs' health. Throughout the experimental period the animals were housed in kennel in separated cages, were exercised three days per week and were taken for a walk 15 minutes daily.

Control (-CLA) and test (+CLA) diets were evaluated and formulated with the same ingredients (Table 1). CLA was added only in the diet which was supplemented with $0.3 \%$ of CLA, reached by addition of $0.5 \%$ of the product. The CLA source used is constituted by colorless liquid oil of vegetable origin (sunflower oil), composed of $60 \%$ of conjugated linoleic acid methyl ester, at the proportion of $1: 1$ of the $-9,-11$ : $-10,-12$ isomers. In the control diet $0.5 \%$ of chicken oil was added so the two diets were isoenergetic. The inclusion of poultry oil to the control food and CLA to the test diet was accomplished by double cone type mixer (35rpm) during 15 minutes to mix $75 \mathrm{~kg}$ of food. The control food was mixed before the CLA food.
Table 1 - Ingredient and chemical composition of diets for dogs supplemented or not with CLA

\begin{tabular}{|c|c|c|}
\hline Item & - CLA & + CLA \\
\hline \multicolumn{3}{|l|}{ Ingredient composition (as-fed basis, \%) } \\
\hline Maize meal (corn meal) & 5.0 & 5.0 \\
\hline Maize corn & 10.0 & 10.0 \\
\hline Soybean meal & 7.0 & 7.0 \\
\hline Brewer's rice & 34.7 & 34.2 \\
\hline Brewer's driest yeast & 1.0 & 1.0 \\
\hline Fish meal & 4.5 & 4.5 \\
\hline Poultry by-product meal & 32.0 & 32.0 \\
\hline Maize oil corn & 1.0 & 1.0 \\
\hline Whole powdered milk & 0.9 & 0.9 \\
\hline Sodium chloride & 0.46 & 0.46 \\
\hline Poultry fat & 0.30 & 0.25 \\
\hline Garlic flavor & 0.004 & 0.004 \\
\hline Vitamine $\mathrm{C}$ & 0.015 & 0.015 \\
\hline Powdered milk flavor & 0.5 & 0.5 \\
\hline Antioxidant (BHT) & 0.020 & 0.020 \\
\hline Milk flavor & 0.025 & 0.025 \\
\hline Yucca schidigera & 0.025 & 0.025 \\
\hline Dried beet pulp & 0.3 & 0.3 \\
\hline Adsorbent (Celpec $®)$ & 0.05 & 0.05 \\
\hline Vitamins-trace minerals ${ }^{1}$ & 0.55 & 0.55 \\
\hline Powdered egg & 0.8 & 0.8 \\
\hline Plasma & 0.8 & 0.8 \\
\hline Mannanoligosacharides & 0.10 & 0.10 \\
\hline LUTA-CLA $60^{2}$ & 0 & 0.5 \\
\hline \multicolumn{3}{|c|}{ Chemical composition (Dry matter basis, \%) } \\
\hline Dry matter & 91.5 & 91.3 \\
\hline Crude protein & 29.2 & 28.3 \\
\hline Acid-hydrolized fat & 10.4 & 10.5 \\
\hline Crude fiber & 1.2 & 1.4 \\
\hline Ash & 10.9 & 10.8 \\
\hline Calcio & 2.9 & 2.9 \\
\hline Fósforo & 1.4 & 1.5 \\
\hline Metabolizable energy $\left(\mathrm{Mcal} \mathrm{kg}^{-1}\right)$ & 3.4 & 3.5 \\
\hline
\end{tabular}

${ }^{1}$ Mineral and vitamin premix (contente $\mathrm{kg}^{-1}$ ): Vitamin. A 16,900IU, Vitamin. D3 - 2,340IU, Vitamin. E - 104mg kg-1, Vitamin. $\mathrm{K}-1.3 \mathrm{mg} \mathrm{kg}^{-1}$, Vitamin. B1 - 3.9mg kg-1, Vitamin. B2 - $6.5 \mathrm{mg} \mathrm{kg}^{-1}$, Pantothenic acid $-19.5 \mathrm{mg} \mathrm{kg}^{-1}$, Niacin $-32.5 \mathrm{mg}$ $\mathrm{kg}^{-1}$, Choline $-1.150 .75 \mathrm{mg} \mathrm{kg}^{-1}$, Zinc $-156 \mathrm{mg} \mathrm{kg}^{-1}$, Iron - 104mg $\mathrm{kg}^{-1}$, Copper - $13 \mathrm{mg} \mathrm{kg}^{-1}$, Iodine $-2.6 \mathrm{mg} \mathrm{kg}^{-1}$, Manganese $45.5 \mathrm{mg} \mathrm{kg}^{-1}$, Selenium $-0.26 \mathrm{mg} \mathrm{kg}^{-1}$, and antioxidant $-240 \mathrm{mg}$ $\mathrm{kg}^{-1}$.

${ }^{2} 60 \%$ of conjugated linoleic acid methyl ester, at the proportion of $1: 1$ of the $9,11: 10,12$ isomers.

Food was offered twice a day and water provided ad libitum. The amount of food per animal was calculated according to daily maintenance of energetic needs ( $\mathrm{kcal} \mathrm{kg}^{-1}$ body weight), following the equation: $132 \mathrm{x}$ body weight $(\mathrm{kg})^{0.75}$, according to NRC (2006), offering the double of the food daily needed. 
The experiment was approved by the Ethic Committee of Animal Research (CEPA) of PUCPR, under registration in CEPA/PUCPR n.23.

\section{Body Analysis}

Each dog was weighed in the initial morning and 120 days after it, before receiving the first meal and evaluated for thickness of the subcutaneous tissue (TSS) using ultrasonography on lumbar region (L7) using a linear transducer $7.5 \mathrm{MHz}$ in a transverse plane. Also, zoometric subjective measurements were performed twice per dog by calculation of body fat mass (FM), according to the equations adapted from BURKHOLDER \& TOLL (1997):

FM in males $(\%)=-1.4(\mathrm{LRH} \mathrm{cm})+0.77(\mathrm{WC} \mathrm{cm})+4$ FM in females $(\%)=-1.7(\mathrm{LRH} \mathrm{cm})+0.93(\mathrm{WC} \mathrm{cm})+5$

Being: $\mathrm{LRH}=$ length of the right hindlimb from the calcaneus tuberosity to the patellar medium ligament.

$\mathrm{WC}=$ waist circumference, circumference of the midpoint between the ileum wing and the last thoracic vertebra, with the standing animal

\section{Biochemistry Analysis}

Before blood collection the dogs were fasted for food, but not for water, for 8 hours. Four blood samples, one per month, were collected in each dog, totalizing seven replications per treatment per month. Approximately $8 \mathrm{ml}$ were used to obtain serum and $2 \mathrm{ml}$ to obtain plasma, using EDTA Serum levels of triacylglycerols (TAG), total cholesterol, low density lipoprotein-cholesterol (LDL) and high density lipoprotein-cholesterol (HDL) were evaluated in the same day of collection or at most 72 hours after. For detection of serum TAG and total cholesterol it was used the enzyme colorimetric test with lipid clarifying factor $\left(\right.$ Human $\mathrm{GmbH}^{\circledR}$ ). For HDL determination it was used the enzyme colorimetric method (In vitro Diagnóstica $\left.^{\circledR}\right)$. The LDL concentrations of very lowdensity lipoprotein-cholesterol (VLDL) were obtained by the equations proposed by FRIEDEWALD et al. (1972):

$\operatorname{VLDL}\left(\mathrm{mg} \mathrm{dl}^{-1}\right)=\mathrm{TAG} / 5$

$\mathrm{LDL}\left(\mathrm{mg} \mathrm{dl}^{-1}\right)=$ total cholesterol $-(\mathrm{HDL}+\mathrm{VLDL})$.

\section{Statistical analysis}

For the evaluation of body measurements, the animals were distributed in a completely randomized design, each dog as an experimental unit. For the serum lipid measurements it was considered a split-plot arrangement, being each dog an experimental unit. The model sums of squares were separeted into diet (mainplot factor), period of blood collection (sub-plot factor) and their interaction (diet x period) effects, with two diets and four periods (months) of blood collection, totalizing seven replicates per treatment per month making fourteen animals as a total.

The variances of the treatments were assessed for homogeneity using the Bartlett test for later analysis of variance using the general linear model functions of SAS (Version 8, SAS Institute Inc., Cary, NC, USA), with means compared by Tukey test at $\mathrm{P} \leq 0.05$.

\section{RESULTS AND DISCUSSION}

There was no difference between groups considering the daily food and energy intake (Table 2) and the variation in body weight $(\mathrm{P}>0.05)$ (Figure 1). However, there were significant differences between final and initial subcutaneous tissue thickness and body fat mass $(\mathrm{P}<0.05)$ of dogs supplemented with CLA (Figure 1).

Dietary CLA properties such as the capacity to reduce body fat and increasing muscle mass in mice, rats and pigs have been previously demonstrated (WHIGHAM et al., 2007). A possible increase in energy expenditure induced by CLA is one of the mechanisms suggested to explain the decrease in body fat, as found in this study.

CHOI et al. (2004) evaluated diets rich in lipids supplemented with a mixture of isomers of CLA or just the isomers 9-cis, 11-trans or 10-trans, 12-cis to $1 \%$ of the diet for eight weeks in rats and noted that the final weight and weight gain were lower for the group receiving the isomer 9-cis,11-trans when compared with other groups. These results suggest that the isomer 9cis, 11-trans modifies the energy balance, especially by increasing energy expenditure. Similar results were obtained by BHATTACHARYA et al. (2006), who reported a decrease in body weight, total body and visceral fat, reduction of serum leptin levels and an increase of energy expenditure and consumption of oxygen in rats supplemented with CLA in the diet.

Table 2 - Food and energy intake of dogs fed with diets supplemented or not with CLA

\begin{tabular}{|c|c|c|c|c|}
\hline & \multicolumn{2}{|c|}{ Treatments } & \multirow{2}{*}{ SEM } & \multirow{2}{*}{$P$} \\
\hline & - CLA & $+\mathrm{CLA}^{1}$ & & \\
\hline Food intake $^{2}$ & 21.3 & 21.5 & 0.7 & 0.94 \\
\hline Energy intake $\mathrm{e}^{3}$ & 144.8 & 154.7 & 18.8 & 0.40 \\
\hline
\end{tabular}




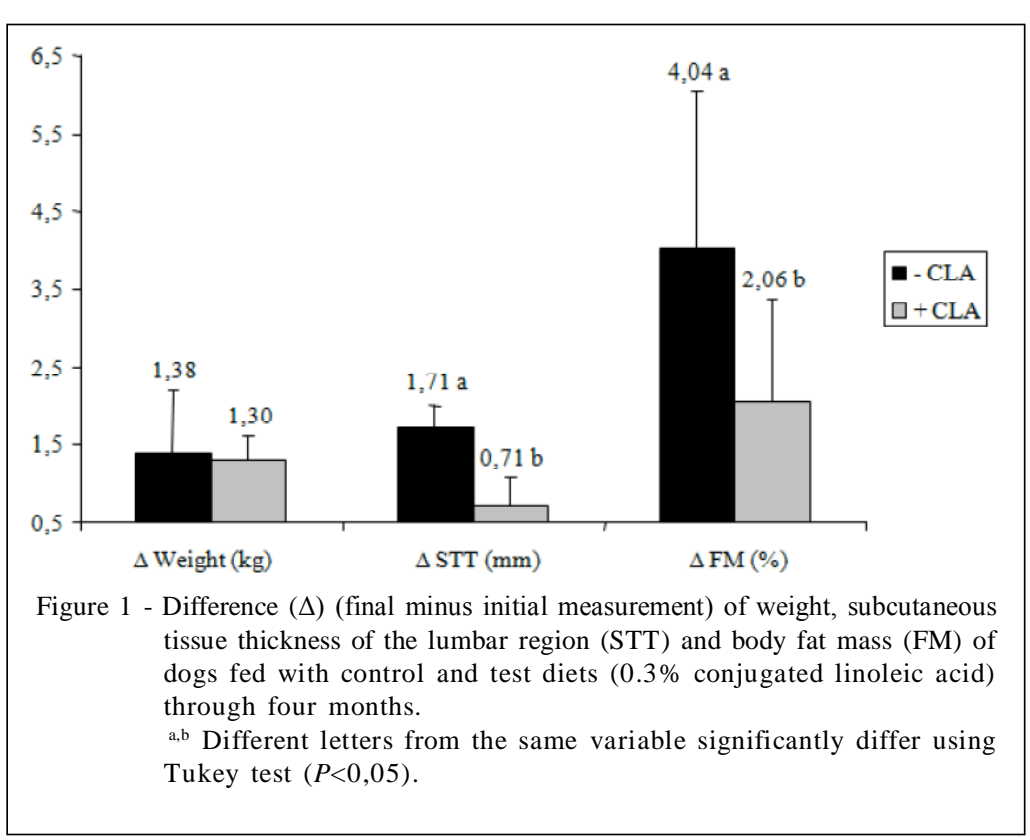

In the current study, there was no difference in energy intake by dogs fed with the diet with CLA supplementation compared with the dogs fed with the control diet. The dogs kept the energy consumption $\left(149.7 \mathrm{kcal} \mathrm{kg}^{-1}\right.$ body weight $(\mathrm{kg})^{0.75}$ day $\left.^{-1}\right)($ Table 2$)$ higher than the recommendation of the NRC (2006) for maintenance of adult dogs $\left(132.0 \mathrm{kcal} \mathrm{kg}^{-1}\right.$ body weight $^{0.75}$ day $^{1}$ ). According to PARK et al. (2007), CLA exerts a modulating effect on fat metabolism independently of the reduction of food intake, which may be more effective in preventing the fat deposition than treating obesity. The authors noted lower fat deposition in mice with CLA supplemented with diets offered ad libitum in relation to controls, however, the same effect was not found in the group supplemented with CLA in the form of food restriction.

There was no significant difference for serum TAG, total cholesterol, LDL and VLDL $(\mathrm{P}>0.05)$, as shown in table 3 , however there were differences between the months of blood collection for all serum measurements. The dogs supplemented with CLA showed higher serum level of HDL in comparison to the control group on the 120 days $(\mathrm{P}<0.05)$ (Table 3$)$.

Despite the large numeric reduction on blood concentration of TAG in dogs supplemented with CLA (Table 3), no statistical difference was found between serum levels of TAG in this study ( $\mathrm{P}>0.05)$, probably due to the high variation among the animals. In the other hand, ZABALA et al. (2006) reported that hamsters fed for six weeks with CLA (1\% of 10-trans, 12-cis of the diet) had greater efficiency and higher weight of gastrocnemius muscle and smaller amount of TAG in the muscle. The authors also observed a decrease in activity of the enzyme lipase lipoprotein and an increase in the activity of carnitine palmitoyltransferase-I. The decline in intake of fatty acids and the increase in beta-oxidation can contribute to the reduction of TAG in the muscle and prevent TAG storage in fat tissue. In vitro studies of LIN et al. (2001) showed that the 10-cis, 12-trans isomer inhibits the secretion of TAG by hepatocytes-G2.

Serum total cholesterol and LDL levels did not differ between treatments $(\mathrm{P}>0.05)$ (Table 2), while serum HDL levels were higher in dogs supplemented with CLA diet $(\mathrm{P}<0.05)$ (Table 3). No studies were found about the effects of CLA on plasma lipoproteins in dogs.

STECK et al. (2007) in one experiment with obese humans receiving $6.4 \mathrm{~g} \mathrm{day}^{1}$ of CLA for 12 weeks, observed an increase in muscle tissue, alkaline phosphatase, C-reactive protein, interleukin-6 and white blood cells and a decrease in hematocrit, hemoglobin and sodium.

Obesity and sources of lipids in the diet affect serum concentrations of fatty acids and levels of blood cholesterol in dogs, as demonstrated by VEIGA et al. (2008). They observed an increasing level of serum cholesterol, TAG and fructosamine in obese dogs, when compared to dogs with normal body scores.

Recent investigations evaluated the isolated isomersand, suggesting that the effects of CLA isomers might be specific. According to SABINE \& PARVEEN (2006), the isomer 10-trans, 12-cis seemed to have effect on blood lipids and little action on the immune system and insulin sensitivity. Metabolic effects of CLA in animal body reported in studies still controversial. Variations in experimental conditions, including the level of CLA, nutritional composition, quantity and form of the dietary supplement, animal weight and age, can contribute to produce those divergent results, moreover, the metabolic rate of each animal body should be considered.

\section{CONCLUSION}

The addition of $0.3 \%$ of CLA on the diet of overweight dogs decreases fat deposition in the lumbar 
Table 3 - Averages of serum triacylglycerol (TAG), total cholesterol, low density lipoprotein cholesterol (LDL), very low density lipoprotein-cholesterol (VLDL) and high density lipoprotein-cholesterol (HDL) of dogs fed with diets supplemented or not with CLA through four months

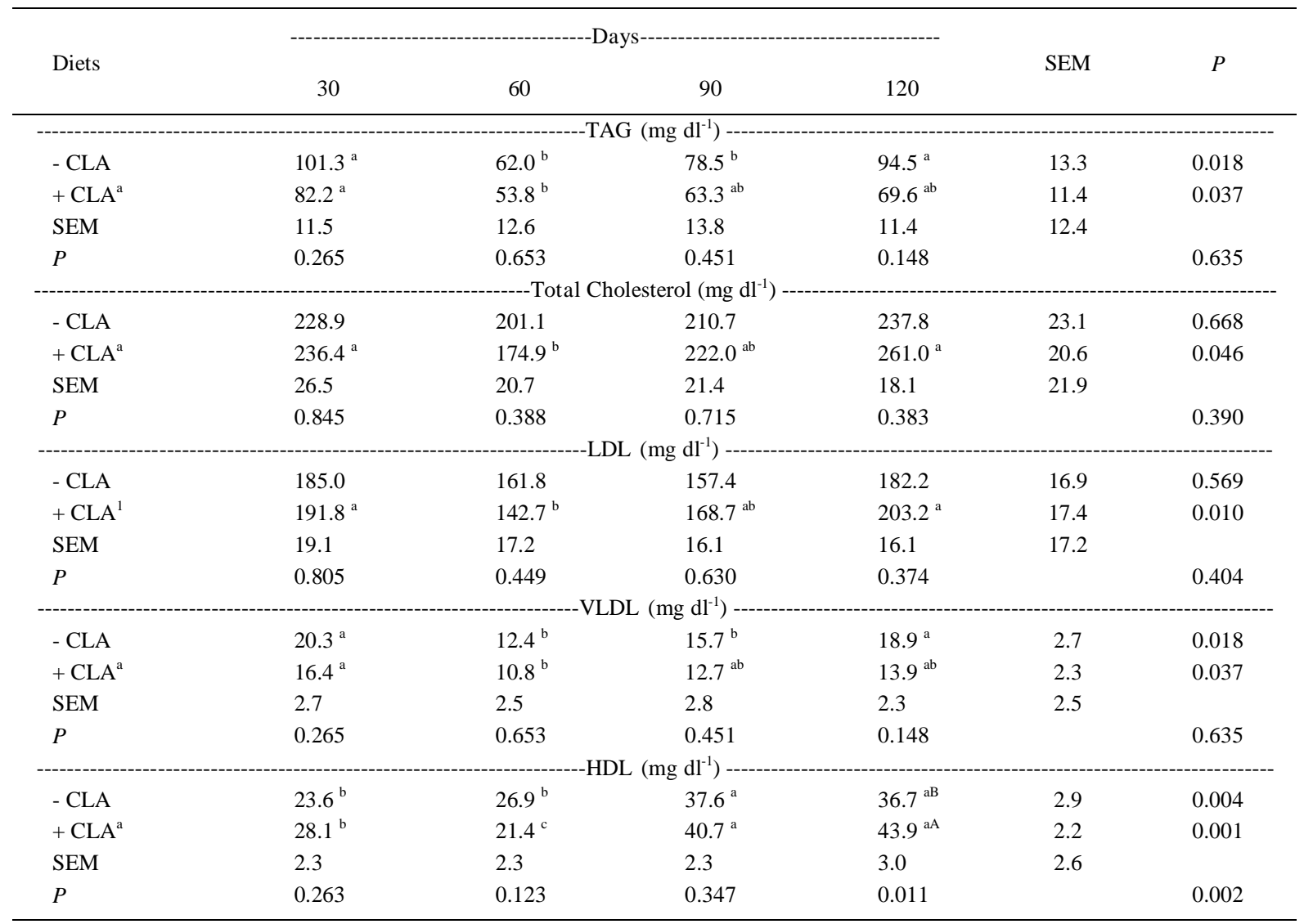

${ }^{1} 0.3 \%$ conjugated linoleic acid

${ }^{a, b}$ Means followed by different small letters in the row and capital letters in the column are different by the Tukey's test $(P<0.05)$

region, accumulation of body fat mass but increases blood levels of HDL. Future investigations, with a larger population sample, with different concentrations of CLA (and its isomers) in a long term assay, might contribute even more to understand the effects of dietary CLA in energy metabolism. With this knowledge CLA could be incorporated in prescription diets in the future for improving body fat distribution and obesity control in selected cases.

\section{REFERENCES}

BHATTACHARYA, A. et al. Conjugated linoleic acid and chromium lower body weight and visceral fat mass in high-fatdiet-fed mice. Lipids, v.41, p.437-444, 2006. Available from: <http://www.springerlink.com/content/176j476497116217/ fulltext.pdf>. Accessed: Mar. 06, 2007. doi: 10.1007/s11745006-5117-3.

BURKHOLDER, W.J.; TOLL, P.W. Obesidad. In: HAND, M.S. et al. (Ed). Nutrición Clínica en Pequeños Animales
(Small Animal Clinical Nutrition). 4.ed. Argentina: InterMédica S.A.I.C.I., 2000. p.475-508.

CHOI, J.S. et al. Effect of conjugated linoleic acid isomers on insulin resistance and mRNA levels of genes regulating energy metabolism in high-fat-fed rats. Nutrition, v.20, 1008-1017, 2004. Available from: <http://www.ncbi.nlm.nih.gov/pubmed/ 15561492>. Accessed: Mar. 05, 2007. doi: 10.1016/ j.nut.2004.08.009.

FRIEDEWALD, W. et al. Estimation of the concentration of low-density lipoprotein cholesterol in plasma, without use of the preparative ultracentrifuge. Clinical Chemistry, v.2, p.499-502, 1972. Available from: <http://www.clinchem.org/ cgi/reprint/18/6/499>. Accessed: Abr. 05, 2007.

GERMAN, A.J. The growing problem of obesity in dogs and cats. Journal of Nutrition, v.136, p.1940S-1946S, 2006. Available from: <http://jn.nutrition.org/cgi/reprint/136/7/ 1940S>. Accessed: May, 042007.

LIN, Y. et al. Conjugated linoleic acid isomers have differential effects on triglyceride secretion in HepG2 cells. Biochimica et Biophysica Acta, v.1533, p.38-46, 2001. Available from: 
<http://kinghub.elsevier.com/retrieve/pii/ S1388198101001378>. Accessed: Mar. 05, 2008. doi: 10.1016/ S1388-1981(01)00137-8

NATIONAL RESEARCH COUNCIL, 2006. Nutrient Requirements of Dogs. revised ed. Washington, DC, 2006. $428 \mathrm{p}$.

PARIZA, M.W. et al. The biologically active isomers of conjugated linoleic acid. Progress in Lipid Research, v.40, p.283-298, 2001. Available from: <http://www.ncbi.nlm.nih.gov/ pubmed/11412893>. Accessed: Mar. 05, 2008.

PARK, Y.; PARIZA, M.W. Mechanisms of body fat modulation by conjugated linoleic acid (CLA). Food Research International, v.40, p.311-323, 2007. Available from: <http:/ /linkinghub.elsevier.com/retrieve/pii/S0963996906001980>. Accessed: Mar. 05, 2008. doi: 10.1016/j.foodres.2006.11.002.

PARK, Y. et al. Conjugated linoleic acid (CLA) prevents body fat accumulation and weight gain in an animal model. Journal of Food Science, v.72, p.612-617, 2007. Available from: <http://www3.interscience.wiley.com/journal/118510086/ abstract?CRETRY $=1 \&$ SRETRY $=0>$. Accessed: abr. 07, 2008 . doi: 10.1016/j.foodres.2006.11.002.

SABINE, T.; PARVEEN, Y. Conjugated linoleic acid and human health: a critical evaluation of the evidence. Current Opinion in Clinical Nutrition \& Metabolic Care, v.9, p.105-110, 2006. Available from: <http:// www.ncbi.nlm.nih.gov/pubmed/16477173>. Acessed: Abr. 07, 2008 .
SHARON, A. Clinical weight management for dogs and cats. In: THE CONGRESS OF THE WORLD SMALL ANIMAL VETERINARY ASSOCIATION IN THAILAND, 28., 2003, Bangkok. Proceedings... Bangkok: WSAVA. 2003. p.56-69.

STECK, S.E. et al. Conjugated linoleic acid supplementation for twelve weeks increases lean body mass in obese humans. Journal of Nutrition, v.137, p.1188-1193, 2007. Available from: <http://jn.nutrition.org/cgi/reprint/137/5/1188>. Acessed: Nov. 05, 2007.

TERPSTRA, A.H.M. Effect of conjugated linoleic acid on body composition and plasma lipids in humans: an overview of the literature. American Journal of Clinical Nutrition, v.79, p.352-361, 2004. Available from: <http://www.ajcn.org/ cgi/reprint/79/3/352>. Accessed: Nov. 05, 2007.

VEIGA, A.P.M. et al. Association of canine obesity with reduced serum levels of C-reactive protein. Journal of Veterinary Diagnostic Investigation, v.20, p.224-228, 2008. Available from: <http://jvdi.org/cgi/reprint/20/2/224>. Acessed: Jan. 25, 2009. doi: $10.1177 / 104063870802000214$.

WHIGHAM, L.D. et al. Efficacy of conjugated linoleic acid for reducing fat mass: a meta-analysis in humans. American Journal of Clinical Nutrition, v.85, p.1203-1211, 2007. Available from: <http://www.ajcn.org/cgi/reprint/85/5/1203>. Accessed: Abr. 07, 2008.

ZABALA, A. et al. Effects of conjugated linoleic acid on skeletal muscle triacylglycerol metabolism in hamsters. Nutrition, v.22, p.528-33, 2006. Available from: <http:// www.ncbi.nlm.nih.gov/pubmed/16458483>. Accessed: Nov. 05, 2007. doi: 10.1016/j.nut.2005.10.005. 